\title{
The Impact of Agency Cost on Demand for Non-Audit Services for Listed Corporations in Jordan
}

\author{
Mohammad Alshawish ${ }^{1}$, Suzan Abed ${ }^{1} \&$ Madher Hamdallah ${ }^{2}$ \\ ${ }^{1}$ Faculty of Economic and Administrative Science, Applied Science University, Amman, Jordan \\ ${ }^{2}$ Faculty of Economic and Administrative Science, Al-Zaytoonah University, Amman, Jordan \\ Correspondence: Suzan Abed, Applied Science University, Faculty of Economic and Administrative Science, \\ Accounting Department, Amman, 11931, P.O. Box (166), Jordan. Tel: 962-6-560-9999 ext. 1558. E-mail: \\ s_abed@asu.edu.jo
}

Received: February 28, 2015

doi:10.5539/ijef.v7n7p154

\begin{abstract}
This study investigates whether agency cost affect companies' demand for non-audit services (NAS). To achieve this objective the data is collected from the financial statements of a sample consists of 122 manufacturing and service corporations listed in Amman Stock Exchange (ASE) for the year 2010. The results showed that there is an impact of both size of the company and leverage on the demand for NAS and there is no impact of block holders' ownership, size of audit firm, performance of the company and sector on the demand of NAS. By this, the results indicated that there is no impact of agency cost on the demand of NAS. Finally, the study recommends future studies to incorporate corporate governance variables to examine the effect of agency cost on non-audit services.
\end{abstract}

Keywords: agency cost, non-audit services, non-audit fees, blockholder

\section{Introduction}

External audits are required to express an independent opinion on the financial statements of companies and to monitor managers' behavior. One of the major management responsibilities is to find external auditor with good reputation to reduce agency cost. Audit report adds value to the financial statements and may reduce cost of capital through the independent verification it provides (Johnstone et al., 2001). However, corporate collapses associated with accounting scandals in the early 21 st Century cast doubt over the independence of auditors and the overall value of auditing (Beattie et al., 1999). That is, if the auditor is not seen to act independently of management, then the audit loses its main role to all parties.

Recently, non-audit services (NAS) which is defined as any services other than audit provided by auditors to an audit customer, have the potential to impair independency of auditors (Ye et al., 2011). Regulators fear that relatively high levels of fees for NAS have the potential to reduce independency of auditors by increasing the economic promise between them and managements (Quick et al., 2013). In this manner, Beattie et al. (1999) pointed out that how an auditor with a legal responsibility to shareholder can handle commercial relation with the management of company and remain independence. Most of previous researches of NAS and its relation with agency costs have been conducted in US, UK and Australia. However, this relationship might be different for Jordanian companies compared with others, due to the fact that most of publically held companies in Jordan are family business which may affect the agency cost.

The rest of this paper is organized as follows: Section 2 defines the problem of the study. Section 3 identifies the objective of the study. Section 4 reviews previous studies and develops the theoretical framework of the study and. Section 5 describes the research methodology used in the study. Section 6 presents the results of the study. Section 7 concludes and recommends future studies.

\section{Problem Statement}

Agency theory deals with the relationship between two parties, where one is a principal who engage other Pearson the other is an agent who represents the shareholder (Jensen \& Meckling, 1976). Agency problems occur as a result of information asymmetry between the two parties. Therefore, the conflicting interest of agent and principal in combination with the existence of information asymmetry between them results in an increase in 
agency cost. In order to solve this problem, the managers hire an external auditor to reduce agency cost.

One of the major public concerns which has emerged from the numerous accounting scandals have been the extent to which audit firms are providing non-audit services (NAS) to their audit clients. Beattie and Fearnley (2010) provided evidence that fees generated from non-audit services is increased rapidly even more than audit fees itself, which may compromise the independence of external auditor. Based on this, the current study tries to answer the following question:

Is there any impact of agency cost on the level of NAS fees paid to external auditors?

From the above question number of sub-questions can be addressed:

1) Is there any impact of blockholders' ownership on the demand of NAS?

2) Is there any impact of size of the company on the demand of NAS?

3) Is there any impact of size of audit firm on the demand of NAS?

4) Is there any impact of performance of the company on the demand of NAS?

5) Is there any impact of leverage on the demand of NAS?

6) Is there any impact of industry classification on the demand of NAS?

\section{Objective of the Study}

The collapse of big companies like Enron in the US has been generally diluted confidence in the world's capital markets. Concern has focused on auditing practices, and particularly on the independence of external auditors. Therefore, question has been raised about how an auditor with a statutory responsibility to shareholders of the company can handle a commercial relationship with the company's management and stay at the same time independent (Beattie \& Fearnley, 2010).

External auditors are important for shareholders because they add credibility to the financial statements. The non-audit services (NAS) have the potential to impair independency of external auditors. The current study tries to investigate whether agency costs affect companies' demand for NAS for manufacturing and service corporation listed on the ASE for the year 2010.

\section{Theoretical Framework and Literature Review}

This study investigates whether agency costs affect companies' demand for NAS for manufacturing and service corporation listed on the ASE for the year 2010-as discussed before. The current section presents the theoretical background of the agency concepts, non-audit fees and the relation between both of them, in addition to underlying the strategies that minimize the agency problem.

\subsection{Agency Cost}

Agency theory describes financial statements and the accounting theories from which they originate as well as to explain their development based on the economic theories of prices, agency, public choice, and economic regulation have been categorized as agency theory. Agency theory is a positive accounting theory that explains accounting practices and standards (Schroeder et al., 2011). It provides a rich theoretical premise for understanding organizational processes and design from principal-agent perspective (Subramaniam, 2006).

An agency model can be viewed to include two parties: the first party is the principal and the other is the agent. The principal is expected to supply the capital, bear risks and to construct incentives, while the agent is required to complete the tasks, bear risks and to make decisions on the principal's behalf (Subramaniam, 2006).

Agency problem occur when the agent work on behalf of the principle in way to maximize the benefit of the (Jensen \& Meckling, 1976). In agency relationships, the principal will seek to minimize the agency costs such as reward and monitor costs, while the agent works towards maximizing rewards and reducing principal control. The basic principal-agent relationship, it is based on two assumptions: (A) the principal and the agent are utility maximizers where both parties seek to maximize their returns, (B) it is not always that the interests of the principal and the agent are aligned (Subramaniam, 2006). The agency problem is likely to increase under conditions of information asymmetry, where one party has an information advantage over another party. It is usually the agent who is seen to possess the information advantage over the principal as he or she tends to be more directly involved in the day-to-day operations of the business. There are many ways to reduce agency cost: (a) hiring external auditing, (b) the effectiveness of internal auditor and (c) the existence of board of director.

\subsection{Non-Audit Services}

Non-audit services are defined as all services provided by an external auditor that are not considered as an audit 
and considered as non-audit income such as advices to management, tax and accounting services (Adeyemi \& Olowookere, 2012). Auditor's independence can be defined as the conditional probability of reporting a discovered breach of contract (Adeyemi \& Olowookere, 2012). DeAngelo (1981) defined auditor independence as the ability to avoid biases and willingness to report a truthful opinion about the fairness of the financial statements. A highly quality audit should reduce stakeholders groups' uncertainty associated with financial statement prepared by managers (Adeyemi \& Olowookere, 2012).

Increasing competition among public accounting firms, following stagnation of external audit revenues in the 1980s, has forced the expansion of Non-Audit Services (NAS) as alternative sources of revenues for these firms. For example, Weil and Tannebaum (2001) showed that companies paid NAS fees, as much as three times the amount paid for external audit services using a sample of 307 Standard and Poor's 500 Consequently, auditor independence is compromised when clients pay for non-audit services.

\subsection{Previous Studies}

This sub-section sheds the light on the empirical studies which attempted to identify the relationship between the agency cost and NAS, the determinants of Non- audit fees and the threats to auditor independence when performing NAS.

Abbott et al. (2003) studied the relationship between non-audit services fees and audit committee using a sample of 538 firms, for the period between February 5, 2001 and June 30, 2001. The results of the study revealed that companies with independent director in the audit committee are likely to have lower NAS fee ratios.

Ghosh and Pawlewicz (2009) examined whether audit fees after Sarbanes Oxley Act (SOX) increases due to increase in both fees and effort. Data collected from Audit Analytics database to collect fees for 23273 firm observations in Compustat for the period 2000-2005. The result of the study confirmed positive relationship between leverage and Demand for NAS. Additionally, the results concluded that the Big 4 audit firms increased their audit fees more than their smaller firms.

Ye et al. (2011) examined the association of a comprehensive set of client relationship bond (audit firm tenure, audit engagement partner tenure and long duration director-auditor relationships) with the level of non-audit services. This study analyzed a data of firms using a sample of 626 firms listed in the Australian Stock Exchange for the year 2002. The results of the study found insignificant relationship for both ownership dispersion and leverage on the demand for NAS. Additionally, they found a positive relationship between closer auditor- client relationships and NAS was moderated by the level of agency cost.

Ibrahim and Samad (2011) aimed to compare corporate governance and performance between family and non-family ownership of Malaysian listed companies; it also examined the governance mechanisms as a tool in monitoring agency costs. In order to achieve the above objectives, a sample of 292 companies listed in the main board of the Bursa, for years (1999-2005) was used. The results of the study concluded that firm value is lower in family firms than non-family firms, while board size, independent director and role duality have a significant impact on firm performance of the in family firms as compared to non-family firms. Additionally, the results confirmed that governance mechanisms have significant impact on agency costs for both family and non-family firms.

Quick et al. (2013) studied the impact of agency costs on the demand for non-audit services (NAS) in Germany; it used a sample of 323 listed firms in Germany Stock Exchange for many segments for the years 2005, 2006 and 2007. The results found that none of alternative proxies for agency conflicts (ownership composition, performance-based management compensation, and leverage) were significantly associated with demand for NAS.

Dobker (2014) examined whether the existence of non-audit services implies threat on auditor independence for 368 listed and family companies in Germany. The results of the study provided weak evidence that non-audit services affect auditor independence. Further, comparative results between listed and family companies revealed that threat is more relevant in family companies rather than listed companies.

\subsection{What Differentiate This Study from Previous Studies?}

All previous studies in this area have been conducted in developed countries; however the current study contributes to the existence literature by examining whether agency costs affect companies' demand for NAS. Up to the researchers' knowledge, this study is the first study conducted in developing context which examine the impact of alternative characteristics derived from agency theory on the demand for non-audit services in Jordan, Moreover, in contrast to previous studies carried out in developed countries, this study employs proxy to measure agency cost (industry classification) which has not been examined in previous studies. 


\section{Research Methodology}

The current study investigates whether agency costs affect companies' demand for NAS for manufacturing and Service Corporation listed on the ASE for the year 2010. This section provides the methods and tools that will be used by the study to accomplish its objectives.

\subsection{Sample of the Study}

The population of the study consists of all manufacturing and service companies listed in ASE for the year 2010. The total number of the companies for the two sectors was 170 companies. The data for non-audit fees were collected from big 5 companies and non big companies. However, the unavailability of Non-audit fees for some of the service and manufacturing corporations for the year of the study results in excluding 48 companies. The final sample of the study consists of 122 corporations for the year 2010.

\subsection{Hypothesis}

The main hypothesis of the study is:

H1: There is no impact of agency cost on the demand for NAS.

\section{From the above hypothesis number of sub-hypotheses is derived:}

H1.1: There is no impact of block holders' ownership on the demand for NAS.

H1.2: There is no impact of size of the company on the demand for NAS.

H1.3: There is no impact of size of the audit firm on the demand for NAS.

H1.4: There is no impact of performance of the company on the demand for NAS.

H1.5: There is no impact of leverage on the demand for NAS.

H1.6: There is no impact of industry classification on the demand for NAS.

\subsection{Model of the Study}

The current study employed the following regression equation:

$$
N A S=\beta 0+\beta 1 B L O C K+\beta 2 C O M S I Z E+\beta 3 A U D+\beta 4 P E R F M+\beta 5 L E V+\beta 6 I N D+\varepsilon
$$

\section{Where:}

NAS: Non audit services.

$\beta 0-\beta 6$ : regression parameters.

BLOCK: Block holders.

COM SIZE: Company's size.

AUD: Size of audit firm.

PERFM: Company's performance.

LEV: Leverage.

IND: Industry (1 for manufacturing corporations, and 0 for service corporations)

$\varepsilon$ : error term.

\subsection{Measurement of the Variables}

\subsubsection{The Dependent Variable}

The dependent variable incorporated in this study is Non-audit services measured by non audit fees. It represents the amount of money paid to audit firms for performing non audit services for the year 2010. It was measured by two proxies; the first proxy is the natural logarithm for non-audit fees paid by the company to audit firm. The second proxy is dichotomous variable equal to 1 for companies with non-audit service and 0 otherwise.

\subsubsection{The Independent Variables}

The independent variables integrated in this study are block holders ownership, size of company, size of audit firm, performance of the company, leverage and industry. These variables measured by the following measures:

Percentage of block holders: is used as a proxy for block holders ownership;

LNTA: Natural logarithm of total asset is sued as a proxy for companies' size;

BIG5: is used as a proxy for size of audit firm performed audit services (Deloitte, PWC, Ernst \& Young, KPMG, 
and in Jordan Grant Thornton Arab Professionals considered as one of the biggest audit company);

Return on Earning (ROE): is used as a proxy for companies' performance;

Debt ratio: is used as a proxy for leverage;

IND: Dichotomous variable equal to 1 for the firm listed as manufacturing company and 0 otherwise.

\subsection{Data Analysis Methods}

The current study employed Ordinary Least Squares (OLS) regression to test the study hypothesis, it also used logistic regression which is used to measure the impact of independent variables (agency cost) on non-audit services (NAS).

\section{Results of the Study}

This section presents the results of the of the study hypothesis and discusses the findings of the study. The section consists of three sub-sections; the first one presents the descriptive analysis of the study variables. The second sub-section presents the result of hypothesis testing. And the third sub-section presents the sensitivity analysis.

\subsection{Descriptive Analysis}

Table 1 presents the descriptive analysis of the study variables.

Table 1. Descriptive analysis

\begin{tabular}{lllll}
\hline & Minimum & Maximum & Mean & Std. Deviation \\
\hline Performance of the company & $-91.27 \%$ & $80.13 \%$ & $-3.9852 \%$ & $27.82068 \%$ \\
Leverage & $2.51 \%$ & $179.48 \%$ & $39.8844 \%$ & $28.80769 \%$ \\
Blockholders' ownership & 0.00 & $99.92 \%$ & $56.7547 \%$ & $27.19509 \%$ \\
Audit Size & 0.00 & 1.00 & 0.4590 & .50037 \\
Company' Size & 6.10 & 8.90 & 7.4942 & .61908 \\
Industry & 0.00 & 1.00 & .4754 & .50354 \\
NAF & 0.00 & 11.03 & 8.3 & 9.07 \\
\hline
\end{tabular}

As seen in the above table, the performance of the company has a minimum and maximum values ranged between $(-91.27 \%)$ and $(80.13$, this highest range indicates the variety in performance and management attitude to achieve their personal interest. However, leverage has a minimum and maximum value (2.51), (179.48\%) respectively; this range indicates the variation in capital structure of the study sample. Furthermore, the blockholders' ownership has a minimum and maximum value $(0 \%),(99.99 \%)$ this means that some companies is totally owned by specific investor and other companies is owned by many investors, take a look at the mean $(56.75 \%)$, this shows that the majority of the companies are owned by blockholders. For the company size, the results show that mean of company size is 7.49 and the standard deviation is 0.62 .

On the other hand the result of descriptive analysis for the dependent variable non audit fees reveals that some companies has no audit fees while other has non-audit fees reached $62000 \mathrm{JD}$ (11.03) with a mean of 3986 (8.3) and standard deviation of 8713.6 JD (9.07) which ensure the variation of fees among companies.

\subsection{Hypothesis Testing}

Table 2. Correlations

\begin{tabular}{|c|c|c|c|c|c|c|}
\hline & Performance & Leverage & Block & Audit size & IND & Company Size \\
\hline Performance & 1 & -.076 & $.276^{* *}$ & .010 & .005 & $.281 * *$ \\
\hline Leverage & & 1 & -.120 & -.024 & .124 & .031 \\
\hline Block & & & 1 & .059 & -.176 & .040 \\
\hline Audit size & & & & 1 & .111 & $.397^{* *}$ \\
\hline IND & & & & & 1 & $-.184 *$ \\
\hline Company Size & & & & & & 1 \\
\hline
\end{tabular}

Note. $* *$ Correlation is significant at the 0.01 level.

*Correlation is significant at the 0.05 level. 
Before run the regression analysis, the data set must comply with the regression assumptions of no collinearity and normality of the residual. Table (2) presents the correlation matrix of the independent variables.

The above Table documents that there is no correlation problem between the independent variables. Furthermore, the above table shows the highest level of correlation depicted between company size and audit size (Pearson correlation $\left.=0.397^{*}\right)$, the table also documents a high correlation between performance and company size, BLOCK and company size.

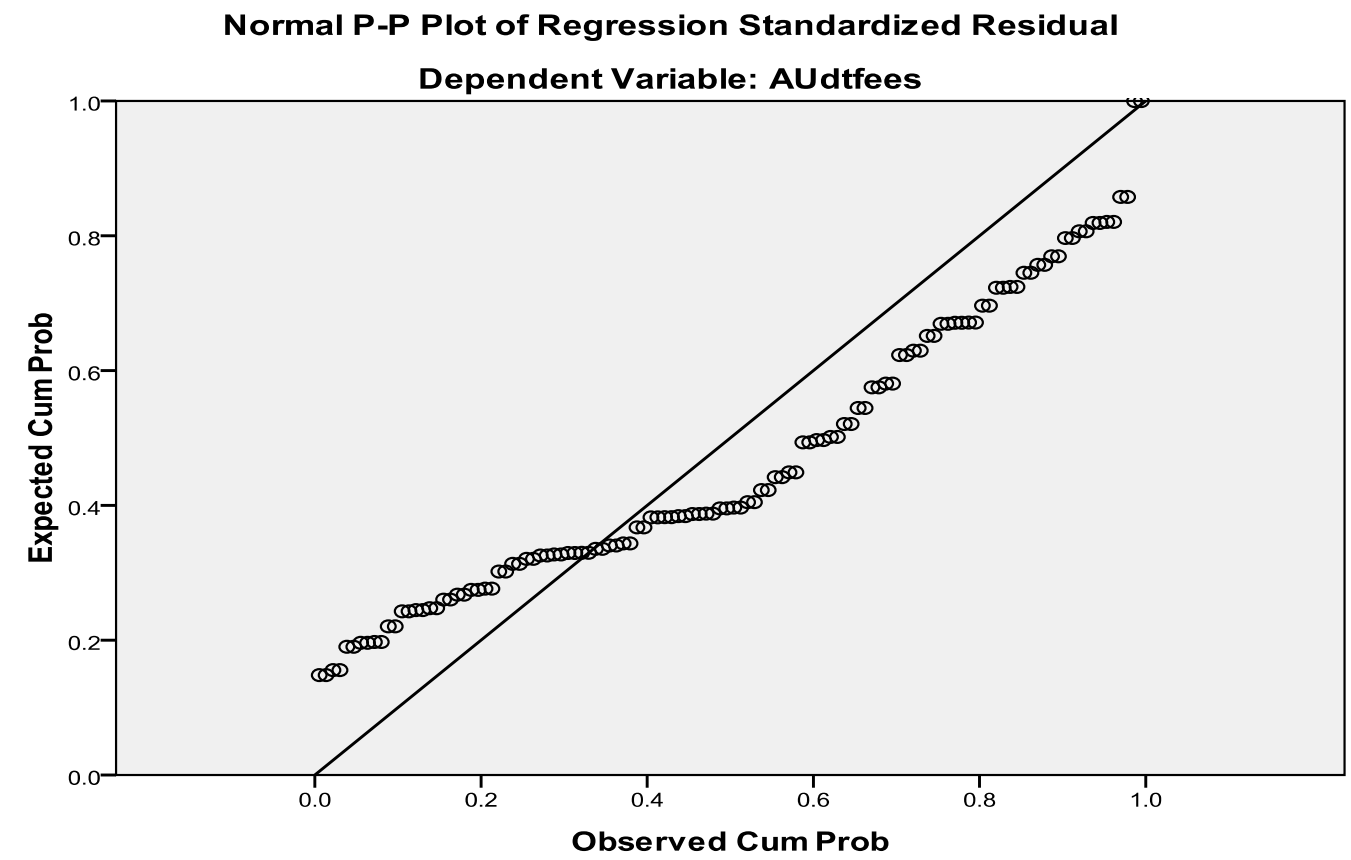

Figure 1. Normality of standardized residual

Figure 1 presents the normal distribution for the residual of the data set. Figure 1 documents that residual of the data set are normal which confirms the normality almost all for the independent variables.

In order to test the impact of the independent variable on the dependent variable the researchers used OLS regression and the results presented in Table 3.

Table 3. The results of OLS regression analysis

\begin{tabular}{lccc}
\hline Variables & B & T & Sig \\
\hline ( constant) & -23548.54 & -2.259 & 0.026 \\
Performance of the company & -10.69 & -0.36 & 0.718 \\
Leverage & 70.99 & 2.586 & 0.011 \\
Block holders' ownership & -39.29 & -1.32 & 0.189 \\
Audit size & 2579.14 & 1.517 & 0.132 \\
Industry & -1423.83 & -0.89 & 0.375 \\
Company Size & 3446.41 & 2.548 & 0.012 \\
F model 3.847 Sig 0.003 & & & \\
Adjusted R square 0.111 & & & \\
\hline
\end{tabular}

As it appeared in Table $3(\mathrm{~F}$ model $=3.847, \mathrm{Sig}=0.003)$ with adjusted $\mathrm{R}$ square was $11.1 \%$, and this means that the collection of the independent variables explain $11.1 \%$ of the variation of the dependent variable. The results of the study revealed that there is no relation between the non-audit fees service and agency cost measure by blockholder's ownership. That is the main hypothesis of the study that there is no impact of agency cost on the demand for NAS has been accepted. This result is quite similar to the result of the study of Quick et al. (2013) and Dobler (2014). This may refer to the nature of some Jordanian family companies which form a large 
proportion of the Jordanian companies, where blockholders do not need NAS because they almost manage and control their companies by themselves. This result is inconsistent with Dobler (2014).

Furthermore, the results confirmed positive and significant relationship between non-audit fees service and company size at $(p$-value $<0.05)$. Also the results documented positive and significant relationship between leverage and non-audit fees service at (p-value $<0.05$ ). This result is contrast with the study of Quick et al. (2013). The reason for this result may relate to the fact that when any company needs to borrow, it needs an endorsement from many certified sides in order to get the approval for borrowing.

On the other hand, the results presented no relationship between non-audit services and the following variables; performance of the company, size of audit firm and industry type. To sum up, the hypothesis that there is no impact of agency cost on the demand for NAS was confirmed.

\subsection{Sensitivity Analysis}

The current sub-section presents the results of sensitivity analysis in order to add robust results of the study. Table 4 presents the OLS regression, using the proxy of (Big 4) instead of using the variable (Big 5) for audit size.

Table 4. The results of OLS regression using Big 4 instead of Big 5

\begin{tabular}{lccc}
\hline Variables & B & T & Sig \\
\hline ( constant) & -21928.87 & -1.907 & 0.059 \\
Performance of the company & -10.77 & -0.357 & 0.722 \\
Leverage & 61.60 & 2.302 & 0.023 \\
Block holders' ownership & -36.05 & -1.207 & 0.230 \\
BIG4 & 1504.51 & 0.857 & 0.393 \\
Industry & -1347.161 & -0.819 & 0.414 \\
Company size & 3348.84 & 2.259 & 0.026 \\
F model 3.184 Sig 0.006 & & & \\
Adjusted R square 0.099 & & & \\
\hline
\end{tabular}

As mentioned in the above table, the results of the study remain robust after change the proxy for the independent variable audit size. In other words, the result of the current analysis is the same as those presented in Table 3.

Moreover, the current study presents the results of logistic analysis instead of using OLS regression. Logistic regression used when the measure of the dependent variable is dichotomous variable. That is instead of using continuous variable to measure the non-audit service; dichotomous variable was used by giving 1 to company with non-audit service and 0 otherwise.

Table 5. The results of logistic regression

\begin{tabular}{llll}
\hline Variables & B & Sig. & $\operatorname{Exp(B)}$ \\
\hline Performance of the company & -0.011 & 0.158 & 0.989 \\
Leverage & 0.005 & 0.523 & 1.005 \\
Block holders' ownership & -0.006 & 0.416 & 0.994 \\
Audit size & 0.276 & 0.533 & 1.318 \\
Industry & 0.092 & 0.822 & 1.097 \\
Company Size & 0.165 & 0.637 & 1.179 \\
Constant & -1.938 & 0.471 & 0.144 \\
Chi square 5.104 Sig 0.531 & & & \\
2 log likelihood 154.422 & & & \\
\hline
\end{tabular}

In logistic regression there is no proxy for goodness of fit test as in OLS regression, because there is no adjusted $\mathrm{R}$ square. Controversially, the presence of a relationship between the dependent variable and independent variables is based on statistical significance of the model's chi-square. The chi-square goodness of fit tests the null hypothesis that the dependent variable is predicted by only including the constant. The probability of the model's chi-square (5.104) is less than .001. Therefore, the null hypothesis that there is no difference between 
the model with only a constant and the model with independent variables is accepted. In other words, this model supports the existence of impact of the independent variables on the dependent variable.

\section{Conclusion and Recommendation}

The objective of this study was to examine the impact of agency cost of non-audit services using a sample of manufacturing and service companies listed in ASE for the year 2010. The result of the study revealed that there is positive and significant relation between both company size and leverage and non-audit services. Overall, the result of the study concluded that agency cost has no effect on the demand for NAS. Based on the finding of this study, the current study recommends future studies to investigate the impact of other mix of variables especially corporate governance variables to study the current objective. Furthermore, the current study provide basement for other studies to investigate whether the existence of non-audit service affect independence of external audit.

\section{References}

Abbott, L. J., Parker, S., Peters, G. F., \& Raghunandan, F. (2003). An Empirical Investigation of Audit Fees, Non-audit Fees and Audit Committees. Contemporary Accounting Research, 20(2), 215-234. http://dx.doi.org/10.1506/8YP9-P27G-5NW5-DJKK

Adeyemi, B. S., \& Olowookere, K. J. (2012). Non-audit services and auditor independence-investors' perspective in Nigeria. Business and Management Review, 2(5), 89-97.

Arens, A., Elder, R., \& Beasley, M. (2012). Auditing and assurance services: An integrated approach (14th ed.). Pearson Education, New Jersey.

Beattie, V., \& Fearnley, S. (2010). Auditor Independence and Non-Audit Services: A Literature Review. Working paper.

Beattie, V., Fearnley, S., \& Brandt, R. (1999). Perceptions of Auditor Independence: U.K. Evidence'. Journal of International Accounting, Auditing \& $\quad$ Taxation, $\quad 8(1), \quad$ 67-107. http://dx.doi.org/10.1016/S1061-9518(99)00005-1

DeAngelo, L. E. (1981). Auditor Independence, "Low Balling", and Disclosure Regulation. Journal of Accounting and Economics, 3(3), 183-199. http://dx.doi.org/10.1016/0165-4101(81)90002-1

Dobler, M. (2014). Auditor-provided Non-audit services in listed and private family firms. Managerial Auditing Journal, 29(5), 427-454. http://dx.doi.org/10.1108/MAJ-07-2013-0908

Ghosh, A., \& Pawlewicz, R. (2009). The Impact of Regulation on Auditor Fees: Evidence from the Sarbanes-Oxlet Act. Auditing: A Journal of Practice \& Theory, 28(2), 171-197. http://dx.doi.org/10.2308/aud.2009.28.2.171

Ibrahim, H., \& Samad, F. A. (2011). Agency Costs, Corporate Governance Mechanisms and Performance of Public Listed Family Firms in Malaysia. S. Afr. J. Bus. Manage, 42(3), 17-25.

Jensen, M., \& Meckling, W. (1976). Theory of the Firm: Managerial Behavior, Agency Costs and Ownership Structure. Journal of Financial 305-360. http://dx.doi.org/10.1016/0304-405X(76)90026-X

Johnstone, K. M., Sutton, M. H., \& Warfield, T. D. (2001). Antecedents and Consequences of Independence Risk: Framework for Analysis. Accounting Horizons, 15(1), 1-18. http://dx.doi.org/10.2308/acch.2001.15.1.1

Quick, R., Sattler, M., \& Wiemann, D. (2013). Agency Conflict and the Demand for NAS. Managerial Auditing Journal, 28(4), 323-344. http://dx.doi.org/10.1108/02686901311311927

Schroeder, R., Clark, M., \& Cathey, J. (2011). Financial accounting theory and analysis (10th ed.). United States: John Wiley and Sons Ltd.

Subramaniam, N. (2006). Agency Theory and Accounting Research: An Overview of some Conceptual and Empirical Issues. In Z. Hoque (Ed.), Methodological Issues in Accounting Research: Theories and Methods, Spiramus (pp. 55-81).

Weil, J., \& Tannebaum, J. (2001). Big Companies Pay Audit Firms more for other Services. The Wall Street Journal.

Ye, P., Carson, E., \& Simnett, R. (2011). Threats to Auditor Independence: The Impact of Relationship and Economic Bonds. A Journal of Practice \& Theory, 30(1), 121-148. http://dx.doi.org/10.2308/aud.2011.30.1.121 


\section{Copyrights}

Copyright for this article is retained by the author(s), with first publication rights granted to the journal.

This is an open-access article distributed under the terms and conditions of the Creative Commons Attribution license (http://creativecommons.org/licenses/by/3.0/). 